\title{
Terrorist Routes in South Eastern Europe
}

\section{Tatiana Busuncian *}

For most transitioning post-Cold War states in Eastern Europe, the period following the shift away from communism and socialism was marked by severe economic recession, increasing debt, hyperinflation, social upheaval, and armed conflict. As a result of these factors, individual nation-states produced large numbers of refugees and migrants who attempted to reach Western Europe. Many of these migrants came from countries with the most unfavorable economies-Romania, Bulgaria, Albania, and Moldova and other former Soviet Republics — or conflict-torn regions. During the 1990s, it was quite difficult to control atypical migration, human trafficking, drug smuggling, and the weapons trade due to unfenced and uncontrolled borders and the breakdown of political and legal systems as a result of recent civil wars and epochal political and economic changes. Today, each country in South Eastern Europe plays some role as an origin, transit, or destination country for trafficked people, weapons, and drugs to Western European countries.

Among the South Eastern European states, the Republic of Moldova exemplifies the experience of this critical region. Demonstrating the irreversible consequences of the migration process, this country's "gray economy" has benefited from the fact that parts of the country-including its long borders with neighboring countries - have remained relatively untouched by the state's central authority. For example, the border with Ukraine extends for 1222 kilometers, 453 kilometers of which lie between Transnistria and Ukraine. The Moldova-Ukraine border contains seventy-six border crossings, twenty-six of which are in Transnistria, out of the reach of the government's central control. Similarly, Moldova's border with Romania covers 862 kilometers and has nine crossings. Cities such as Tiraspol and Odessa (in the direction of Europe) and the countries of Turkey (on many routes to southern European destinations), Poland, and Russia (destinations for trafficking routes from the Middle East) are seen as being key junctures along regional trafficking routes. ${ }^{1}$

According to non-governmental sources, it appears that traffickers are seeking to diversify the countries of destination for their "products," and that a new channel now leads to Central Europe and the Arab world. From 1991 to 2005, the number of individuals transiting through the Republic of Moldova on their way to Central European countries was greater than the total number of people residing in Moldova. These conditions were allowed to arise through the lack of an adequate legal framework in the Republic of Moldova.

Tatiana Busuncian is the Director of the Pro Marshall Center of the Republic of Moldova.

NATO Parliamentary Assembly, "Mission Reports - Visit to Moldova by the Subcommittee on Democratic Governance [Civil Dimension of Security]," 1-4 March 2004; available at www.nato-pa.int/default.asp?shortcut=484. 
In order to take concrete steps against the spread of this phenomenon, the majority of the southeastern European states have joined with the general international force involved in the "global war on terrorism." The Republic of Moldova has declared its support as well, and has begun collaborating with all parties interested in fighting terrorism. Moldova's participation in the anti-terrorist coalition is explained by its location in South Eastern Europe, which situates it within the so-called instability train that stretches from southwestern Asia, through the Caucasus, and on to the Balkans. This region has a significant presence of terrorist and extremist groups.

Though illegal migration is a problem, various sources disagree as to its severity. The microfinance organization Alliance of Moldova conducted an independent public opinion poll in 2004 that investigated illegal migration in the country. The results indicated that 265,000 to 285,000 Moldovans had left the country that year looking for jobs or for other financial reasons. ${ }^{2}$

According to statistical data, as of the end of 2006, 426,000 adults had left Moldova to work abroad through various legal channels since 2003. Official data regarding legal and illegal migration in 2003 and 2004 indicate that the annual stream of migrants was much smaller, only increasing from 5,000 to 9,000 during that period. Meanwhile, media sources have stated that there are over one million Moldovans working abroad. ${ }^{3}$

The increasing illegal migration of Moldovans to Western countries has become an international problem. Interviews with state officials, migration experts, and returned migrants indicate that the main destination countries for Moldovan migrants, in decreasing order of importance, are Russia, Italy, Ukraine, Romania, Portugal, Spain, Greece, Turkey, and Israel.

According to expert opinion, the "Western channel" used by illegal migrants crosses Moldova, and has two main routes:

- Ukraine-Moldova-Romania-Hungary, and then to Western countries

- Russia-Moldova-Romania-Hungary, and then to Western countries.

Generally speaking, the absence of a coherent policy and of adequate control mechanisms aimed at the phenomenon of trans-border migration has generated multiple negative consequences within Moldova, including:

- The presence of foreign communities within Moldova that are ethnically, linguistically, religiously, and culturally distinct from Moldovans. These communities may face major difficulties in adapting to the country and in establishing good relationships with local citizens. These differences can also constitute potential sources of conflict among immigrant groups.

2 B. Ghencea and I. Gudumac, Labour Migration and Remittances in the Republic of Moldova (Kishinev, Moldova: Microfinance Alliancea; and Chisinau: Soros in the Republic of Moldova, 2004).

3 Informative note for the National Migration Department of the Republic of Moldova on "Trafficking in Human Beings," 2003-04. 
- The involvement of different organized crime structures in the trafficking of human beings, drugs, and weapons. This involvement also increases the possibility that migrants, many of whom are in extremely vulnerable situations, can be easily recruited by different organized crime structures to aid in the trade in drugs, weapons, ammunition, and stolen vehicles.

- The tendency of a significant number of foreigners to earn their living through some form of illegal activity, often in complicity with local criminals.

- The appearance of more commercial companies serving as fronts for illegal activities.

- The possibility that some migrants - along with local citizens or even members of various extremist terrorist organizations - may become affiliated with extremist Islamic groups and ideas.

- The increase of state expenditures, including expenses related to the repatriation of migrants to their countries of origin, detainment costs for illegal immigrants, and other forms of support for asylum seekers or refugees.

The following routes were identified as those that are most frequently used for criminal movement:

- Botosani District: routes extending from Odessa-Kiev-Berza; Moscow-KievManoleasa; or Moscow-Kiev-Cernauti-Herta-Racovat

- Iasi District: routes extending from Moscow-Kiev-Chisinau-Iasi-Bucharest; or Moscow-Kiev-Chisinau-Oradea

- Vaslui District: routes extending from Moscow-Kiev-Chisinau-Rasesti-Stanilesti (Albita)-Bucharest

- Galati District: routes extending from Reni (where the Prut River flows into the Danube)-Chiscani-Bucharest

- Braila District: routes extending from Reni-Gura Prut-Stancuta-Bucharest.

Additionally, in the western part of Moldova, which borders Romania, there appears to be a high volume of illegal border crossings by African and Asian migrants. Some of these migrants are said to be working for criminal syndicates from former Soviet states, including Russia, Ukraine, and Moldova, as well as with local contacts. Many of these migrants entered the country through the eastern or southern borders and, along with some local citizens, have a determined goal of reaching Western Europe. The main routes used by these migrants are:

- Satu-Mare District Inspectorate of the Frontier Police: this route extends from Istanbul to Sofia to Bucharest or Moscow, then on to the eastern frontier of Romania and Bucharest, shifting to Satu-Mare through two directions: BucharestCluj Napoca-Zalau-Baia Mare-Satu Mare, or Bucharest-Timişoara-OradeaSatu Mare 
- Bihor District Inspectorate of the Frontier Police: this route extends from Bucharest-Arad-Oradea-Carei

- Arad District Inspectorate of Frontier Police: this route extends from Iasi-Bucharest-Arad or from Giurgiu-Bucharest-Arad. This route also follows the railway route Bucharest-Curtici-Lokoshaza-Budapest.

The third area in the region where trafficking of human beings has reached a high volume is the southern portion of Romania, bordering Bulgaria. This area is used for the illegal entrance of African, Asian, or Kurdish individuals that transit the country in order to get to Western Europe. This area is also used for the illegal exit of persons from the Commonwealth of Independent States (CIS). In addition, it is used by some Romanian citizens to reach Greece or Turkey. The following routes are used in this region:

- Giurgiu District Inspectorate of the Frontier Police: routes from Edirne-VarnaGiurgiu-Bucharest or from Edirne-Varna-Tolbuhin-Russe-Giurgiu-Bucharest

- Constanta District Inspectorate of the Frontier Police: routes from IstanbulDuran Kuluk-Vama Veche-Bucharest to Arad, Oradea, or Timisoara. Along this route, falsified Bulgarian passports are used to facilitate the entrance of Kurdish migrants into Hungary

- Dolj District Inspectorate of the Frontier Police: routes from Timisoara-BechetBulgaria-Greece. Here, Romanian, Bulgarian, and Serbian citizens illegally transport migrants across the Romanian border using shipping or mercantile activities as a front. These traffickers use tracks that bypass the official border control points of the frontier.

The next segment of the region where trafficking is a concern includes Romania's border with southeastern Ukraine and the Romanian coastline, where persons from former Soviet territory, Africa, and Asia illegally enter and exit the country using the following routes:

- Tulcea District Inspectorate of the Frontier Police: this route extends from Moscow-Kiev-Odessa-Ismail-Bucharest to the western and southwestern frontiers of Romania and on to Western Europe

- Constanta District Inspectorate of the Frontier Police: Romanian, African, or Asian individuals, who have previously tried and managed to illegally enter or exit the country by hiding in cargo ships in the Romanian seaport, use this area.

Illegal crossing of the country's border, coordinated by well-organized international criminal groups, can also be detected in the southwestern region of Romania, bordering the former Yugoslavia. The groups from this area aim to transit foreign or Romanian migrants from the former Yugoslavia to Greece or Italy. At the same time, they also manage to traffic human beings, especially young girls from former Soviet regions. The criminal groups are composed of Romanian citizens, Serbians, and others from former Soviet countries, including Russia, Ukraine, and Moldova. The routes 
they use go through the Mehedinti District Inspectorate of the Frontier Police, running from Drobeta Turnu Severin (which is the starting point for the Romania-Greece route), continuing to the border control points of the frontier at the Iron Gates, on to the Serbian cities of Negotin and Presova, and through Macedonia to Gevgelija (located near the Macedonian border), with Athens as the termination point.

The members of these groups are Romanian, Russian, Ukrainian, Moldovan, Serbian, Macedonian, and Greek citizens that illegally remove young girls from Moldova and transport them via the Danube River by ship to the former Yugoslavia, where they are forced into prostitution. The following routes are used for these activities:

- Iasi-Bucharest-Craiova-Drobeta Turnu Severin-Orsova-Moldova Veche, or Chisinau-Galati-Bucharest-Drobeta Turnu Severin-Orsova-Vinita

- Timis District Inspectorate of Frontier Police: routes from Timisoara-Jimbolia; Timisoara-Moravita-Vatin; Timisoara-Sannicolau Mare-Cenad; or TimisoaraBeba Veche. ${ }^{4}$

Northern Romania, bordering Ukraine, is especially significant for the analysis of this illegal phenomenon, due to the frequency of human trafficking in this region and the high number of African and Asian individuals living within Ukrainian territory. Migrants cross this border through legal means, using false documents, or with the support of guides from neighboring states, who often play an integral role in these international human trafficking routes. The general conclusion is that the illegal migration phenomenon, in all of its manifestations, is significant from all points of view. Moldova and Romania are among the most important transit areas for illegal migration in South Eastern Europe.

To regulate the flow of foreign citizens in Moldova- both those using the country as a transit point and those remaining without any means of support - the country's National Bureau for Migration (NBM) is working to improve the verification of visas requested by foreigners and the tracking of foreign citizens in Moldova. The majority of foreign citizens attempting to illegally exit Moldova reportedly enter the country with authentic documents and visas, which are later destroyed, making it difficult to identify, verify, and deport these migrants.

The evolution of Moldova's asylum policy can be better understood by examining the policies of neighboring countries. In Romania, 90 percent of those who petition for refugee status have entered the country illegally via the main established routes: Russia-Ukraine-Moldova and Iran/Iraq-Turkey-Bulgaria.

The dramatic terrorist attacks of 11 September 2001 provided a true wake-up call to the international community. The loss of human life and the spectacular material damages caused by the attacks increased worldwide awareness of international terrorism. Immediately, joint actions and efforts were undertaken to counteract this global danger. In fighting global terrorism, one essential issue must not be overlooked: the

4 "Migration, Employment and Poverty Reduction," Official Report presented to the Moldovan Government by the Ministry of Health and Social Protection, April 2005. 
strong correlation between terrorism and organized crime. The existence of well-established networks, the substantial profits to be earned from illegal activities, and an existing infrastructure for recruiting and training new members, moving equipment, and funds without being detected are all attractive reasons for terrorist groups' participation in organized crime.

South Eastern Europe is a zone of particular interest in this intersection between terrorism and organized crime. It has a high level of criminal activity, which contributes to the further extension and flourishing of terrorism. In 1990, when most South Eastern European countries began the transition to independence, organized criminal groups - typically descendants of the former Soviet "thieves in law"-functioned but were, especially in Moldova, dismantled. Later, new types of criminal organizations appeared. These groups were often under the control of people who had no criminal record, and are usually involved in activities connected to trafficking of human beings, drugs, and weapons, such as:

- Recruiting young women for sexual exploitation. This includes the trafficking of women to Turkey, Greece, Kosovo, and other countries through Romania, Bulgaria, Albania, etc. Today, Moldova cooperates with other countries in efforts to counter this activity.

- Trafficking laborers to Western countries through South Eastern Europe. In these cases, the criminal groups operate through tourist agencies, which prepare the documents for migrants to enter the countries as tourists. Clients are instructed on how to behave so they will not arouse the suspicion of consulate staff or border guards. It is difficult to discover migrants who will give evidence or serve as witnesses against such companies.

- Facilitating the illegal migration of Southeast Asian, Middle Eastern, and African migrants. ${ }^{5}$

These illegal activities are possibly providing terrorist organizations with opportunities to use established channels for their own purposes. Information collected by the Information and Security Service of the Republic of Moldova from 1991 to the present confirms this. From 1992 to 1996, officials identified cases where the members of the Sri Lankan terrorist organization, the Tamil Tigers of Liberation Eelam, were transiting the country in small groups on their way to Western countries. ${ }^{6}$

Organized crime takes many forms and involves a wide variety of criminal activities, yet there is one illicit market that is considered to be a major threat in virtually all European countries: drug trafficking. While it is true that terrorists and drug traffickers have different long-term objectives (political goals for terrorists and economic ones for drug traffickers), they often share some short-term goals. Nearly every terrorist group raises some money from the drug trade. According to the U.S. Drug Enforcement Ad-

5 Extracted from the report presented at the PfP Counter-Terrorism Working Group (CTWG) meeting in Moldova by Mr. Ion Ambroci, 26-27 June 2006.

6 Ibid. 
ministration, "narcoterrorism" refers to terrorist acts carried out by groups that are either directly or indirectly involved in cultivating, manufacturing, transporting, or distributing illicit drugs. ${ }^{7}$ Therefore, the term refers to groups that use drug trafficking to fund terrorist activities. According to institutions that deal with this issue, it is certain that organized crime, and especially drug trafficking, represents the most important source of financing for terrorist groups, providing 30-40 percent of their funds. In fact, it is widely accepted that the main threat to international security is no longer statesponsored terrorism, but terrorist acts carried out by "unregimented networks"groups or individuals increasingly motivated by money obtained through organized criminal activity, mainly the traffic in illegal drugs.

The relationship between terrorist organizations and drug-trafficking groups is a "mutually beneficial one that allows exchanges of drugs for weapons, use of the same smuggling routes, [and the] use of similar methods to conceal profits and fund-raising." Even transitional countries are used as trafficking routes for illegal drugs; once they are established, these networks tend to become increasingly well-organized and hard to detect. South Eastern Europe is a very complex region that has experienced conflict and political instability since the beginning of 1990 s, which created the necessary conditions for the establishment of criminal networks and the development of criminal activities, including drug trafficking. The western Balkans (including BosniaHerzegovina, Serbia, Montenegro, Albania, and, to a certain degree, the Former Yugoslav Republic of Macedonia) are still considered to be "the gateway of organized crime to Europe," which raises the specter of the potential for terrorist activities in, or emanating from, the area. It is obvious that the greatest peril connected with terrorism in the region, directly or indirectly, is organized crime. It represents not only a funding source for terrorism, but also a basis for recruitment of new people and material support.

The strategic position of the region, between Western Europe and the Middle East, adds a new dimension to the link with terrorism. For instance, according to the Centre for Peace in the Balkans, it has been confirmed that terrorism in the Balkans has been primarily financed through drug trafficking. Heroin is the most profitable commodity on the Western market; a kilogram of heroin, worth USD 1000 in Thailand, has a wholesale value of USD 110,000 in Canada, with a retail street value of USD 800,000. ${ }^{9}$ Thus, South Eastern Europe is a bridge between the Middle Eastern and Central Asian drug producers and the Western European drug consumer market. Via

7 Asa Hutchinson, Congressional Testimony before the Senate Judiciary Committee's Subcommittee on Technology, Terrorism and Government Information about Narco-Terror: The World Connection between Drugs and Terror, 13 March 2002; available at www.usdoj.gov/ dea/pubs/cngrtest/ct031302.html.

8 Rex A. Hudson (Project Manager), “A Global Overview of Narcotics-funded Terrorist and Other Extremist Groups" (Washington, D.C.: Federal Research Division, Library of Congress, May 2002); available at www.loc.gov/rr/frd/pdf-files/NarcsFundedTerrs_Extrems.pdf.

9 "Balkan-Albania-Kosovo-Heroin-Jihad, Research Analysis" (Toronto: The Center for Peace in the Balkans, May 2000); available at www.balkanpeace.org/our/our3.shtml. 
the Balkan route, heroin travels through Turkey, Macedonia, Kosovo, and Albania to Western European markets. ${ }^{10}$ Antonio Maria Costa, executive director of the United Nations Office on Drugs and Crime (UNODC), recently remarked that "the revenue generated by organized crime offers terrorist groups a steady flow of funding, making the effort to eliminate drug trafficking and to reduce drug abuse critical strategies in the global fight against terrorism." As it has become increasingly difficult to "distinguish clearly between terrorist groups and organized crime units, since their tactics overlap," we are now witnessing "the birth of a new hybrid of organized crime-terrorist organizations," which requires cutting off the connection between crime, drugs, and terrorism. ${ }^{11}$

The Republic of Moldova, which has been labeled as Europe's poorest country, is now a link in the chain referred to as the "Balkan way" of drug transit. The drug smuggling channels in Moldova are also sometimes used by members of terrorist organizations to raise money for their other activities. According to the calculations made by the Moldovan Ministry of Health and recent data of the Ministry of Internal Affairs, there are an estimated 60,000 to 65,000 drug consumers in the country; hashish accounts for 150 million lei and opium for 850 to 900 million lei of profit per year. ${ }^{12}$ It is important to note that, for each registered person in this country, an estimated ten people are left unregistered, indicating that the real totals may be even higher. Heroin, hashish, and cocaine from Turkey, Bulgaria, and Romania cross Moldova on their way to Western Europe. In the opposite direction, they travel through Moldova on their way to Central Asia.

Statistics from customs control agencies in neighboring countries-like Bulgaria, for instance - reflect a much higher level of drug transit from Moldova. Bulgarian customs confiscated more than 42 kilograms of heroin from a Turkish bus service that regularly connects Turkey to Moldova. The criminal organizations controlling the networks between Turkey and Moldova originate in the countries of the former Soviet Union, and their operators are mainly Russians, Ukrainians, and nationals of Caucasian countries. However, as has been observed in the neighboring Ukraine, Kurdish networks are also active in Moldova. ${ }^{13}$

Ukraine is another southeastern European country experiencing drug trafficking issues, especially increased drug trafficking from Afghanistan. A significant growth in Ukrainian drug use over the last few years has increased the demand for drugs and has created a robust infrastructure within the informal drug trade. Additionally, an insufficient level of cooperation among law enforcement agencies at the regional level has

10 Ibid.

11 United Nations, "UN Warns about Nexus between Drugs, Crime and Terrorism," UN Press Release SOC/CP/311 (1 October 2004); available at www.un.org/News/Press/docs/2004/ soccp311.doc.htm.

12 The Official Report, "Analysis on Narcotics Situation in the Republic of Moldova," 1 February 2005.

13 Centre for Geopolitical Drug Studies, "Moldova-A Bridge for Trafficking," Geopolitical Drug Newsletter 7 (April 2002); available at www.geodrugs.net. 
significantly reduced the efficiency of anti-drug activities. Despite a prohibition on the cultivation of narcotic plants (poppy straw and hemp), over 5,000 cases of illegal cultivation by private households have been discovered in Ukraine. ${ }^{14}$ Information from the Security Service of Ukraine indicates that during the last several years there has been an increase in illegal operations that traffic in synthetic drugs, including amphetamines, and in the domestic production of these substances, with the involvement of highly educated chemical industry specialists. Before entering Ukraine, drugs pass through a number of countries and areas, including Russia, the Caucasus, Turkey, Romania, Moldova, and Poland. Criminal groups use Ukraine's seaports and rivers as part of the "Balkan route" for drug smuggling. Shipments are usually destined for Western Europe, and arrive by road, rail, or sea, which are perceived as less risky modes of transport than air or mail shipment. According to the State Customs Service, the main channels of drug trafficking through Ukraine are as follows: Turkey-southern border of Ukraine-western border of Ukraine-Western Europe; Latin America-northern European sea ports-Baltic states-Ukraine-Western Europe; and Central African countries-the Middle East-southern border of Ukraine-western border of Ukraine-Western Europe.

In the case of Moldova, the relationship between terrorism and organized crime can be observed within the framework of the Transnistrian problem. The Moldovan region of Transnistria is flooded with criminal groups and illegal arms dealers, with transnational criminal and terrorist organizations skillfully using these separate sectors to their advantage. The most dangerous organized criminal operations are creating their own military units and illegally producing and selling arms and explosives. In fact, these organizations create not only paramilitary units, but also whole armies, especially in regions with separatist governments. In the early 1990s, separatist regimes equipped their own armies by seizing the armaments and military equipment of former Soviet troops. There is some evidence that, during this time, official structures of some countries transferred weapons and ammunitions to certain separatist regimes under private agreements.

Organized criminal groups sell conventional arms, including guns and rifles, which can be easily procured from ammunition dumps used by the 14th Russian Army, which was dislocated in the separatist region of Transnistria. The Information and Security Service of the Republic of Moldova received information about Middle Eastern (Palestinian) interests in the armaments present in this region. The activity of the EU commission monitoring the Transnistrian portion of the Moldovan-Ukrainian border had already shown that trafficking of human beings and drugs is occurring here. According to the head of the External Intelligence Service of Romania, Gheorghe Fulga, the Transnistria region is in the field of vision of the fundamentalist groups Hezbollah, Mujahedeen-e-Khalq, and the Muslim Brotherhood, which aim to purchase ammuni-

14 Country Factsheets Eurasian Narcotics: Ukraine 2004," available at www.silkroadstudies.org/ new/inside/research/narcotics_crime/FactSheet/2004/Ukraine.pdf. 
tion and to involve particular firms in bringing insurgents to the West and the Caucasus. $^{15}$

In Moldova, the existence of a shadow economy, coupled with severe poverty, has exacerbated the level of criminality in post-Soviet society. The desperate economic situation has created new opportunities for the "communist mafia" to take control over much of the economic and political life of this small nation. The Ministry of Interior, with its small force of 12,000 poorly equipped officers, cannot keep pace with the broad range of criminal activities that are overwhelming Moldova. The money that fuels the shadow economy comes from illegal trade in tobacco, petroleum, and alcohol as well as from an underground armaments trade that reaches all the way from Chechnya to Libya.

The attraction of Moldova for criminal elements in the former Soviet Union is illustrated by a recent case in which a Georgian citizen, who came to Moldova in 1997, organized a criminal group that traded in both armaments and drugs. When the Georgian was arrested, it was revealed not only that he had a varied store of weapons and drugs, but that he also boasted an impressive collection of false identity cards for Georgia and Ukraine.

An investigation of these illegal activities led to the disclosure that the Moldovan weapons trade extended to anti-aircraft missiles left behind by Soviet forces. While these missiles could have been used against airplanes, investigators learned that missile components had been used in eight attempts to destroy buildings, corporate headquarters, or houses of businessmen who resisted blackmail and other pressures to contribute to criminal "banks." The latest two of these explosions occurred on 6 July and $13 \mathrm{Au}$ gust 2006 in Transnistria, demonstrating once again the lack of government control in the region and the presence of such armaments on Transnistrian territory. Explosives of this caliber routinely come from Transnistria and the warehouses of the operative troops of the Russian Army. A large depot of armaments that belonged to the former 14th Russian Army in Colbasna is now under the control of separatist paramilitary forces, which sell them to criminal groups around the world. ${ }^{16}$

According to an investigation by British journalists, any person - whether a political terrorist or religious fanatic-who possesses a necessary sum of money can easily acquire weapons in Transnistria that can pose a contamination threat to millions of people. The British journalists came very close to purchasing Soviet radioactive devices in Transnistria for USD 167,000 per item. The journalists refrained from finaliz-

15 Tatiana Busuncian, "Terrorism and Organized Crime" report presented within the "NATO Defense against Terrorism Course," M5-66, the NATO School, Oberammergau, Germany, November 2004 and February 2005.

16 See Zaur Borov and Stephen Bowers, "Illegal Weapons Traffic in Eastern Europe," Nelson Institute Research Report (Harrisonburg, VA: Nelson Institute for International and Public Affairs, James Madison University, 2002). 
ing the transaction only because the negotiation got so far that following through with the deal would have been an illegal act. ${ }^{17}$

Researchers and their sources have tried to identify the main routes used for smuggling weapons. By rail, the weapons travel from Rabnita to Slobodna, Ukraine, then south to the Ilichovsk or Odessa harbors. The cargo then travels by sea, where it can go in any direction. Another permutation of this route is Tiraspol to Razdelinaia, Ukraine, then on to Ilichovsk and Odessa. A second transport route is the auto route. Avoiding customs checkpoints, military trucks transporting weapons have been noticed in the swampy areas of Moldova's border with Ukraine, in the region of Gradenitsy. The weapons traffic does not avoid the right side of the Nistru River, either. Well-informed sources say that, at one point, the phenomenon had amplified due to the rampant corruption that existed in the Republic of Moldova. From 1999 to 2000, according to this information, two assembly lines from a cartridge manufacturing factory were taken out through Cahul customs. The merchandise was declared as machinery for corn husking. During the same period, a plane belonging to a Ukrainian company, loaded with over 5,000 pistols, was detained in the Chisinau airport. Until a "consensus" was reached, the plane was held for almost a year at the airport, and nothing is known about the fate of the load. Consequently, the network of weapons traffickers has huge ramifications on the right side of the Nistru. The few cases initiated by the prosecutor's office dealing with weapons trafficking have long since gathered dust somewhere in the prosecutor's files. ${ }^{18}$

Another case illustrating the illegal traffic of weapons from the Transnistrian region concerns events that occurred in Chechnya and Abkhazia, a separatist region in Georgia, in the fall of 2001. The Russian television channel ORT showed a cache of weapons seized by the Russian military during operations against a Chechen guerrilla squad. Among the captured weapons there were "Vasilioc" model mortars. Such mortars have only been produced at the Ribnita Metallurgical Plant in recent years. Moreover, the design and testing of these weapons was performed by Russian military experts. It is also known that the leader of the Abkhazian secessionists expressed his gratitude for equipment and munitions used to fight against the Georgian Army in a letter addressed to the Tiraspol separatist authorities and the Transnistrian commandos. Other sources say that Tiraspol has sold seven "Grad" installations and an imposing number of automatic rifles to Abkhazian separatists. A "Grad" rocket launcher installation costs at least USD 5,000, while a Kalashnikov assault rifle costs from USD 150 to $300 .{ }^{19}$

Another known example is the connection with the "Electroaparatnyi" plant in Tiraspol, which mainly produces household articles. In 2004, this plant imported sophisticated equipment based on diamond technology from the Russian Federation at a cost of USD 2 million. Experts say it was impossible for the plant to use this kind of equip-

17 See Brian Johnson Thomas and Mark Franchetti, "Radioactive Rockets 'For Sale' in Breakaway Soviet Republic," Times (London) (8 May 2005); available at www.timesonline.co.uk.

18 Journalistic Investigations Center, "Guarding the Rusty Cartridges as Shield for Modern Military Technology" (2004); available at www.investigatii.md/eng/index.php?art=96.

19 Ibid. 
ment to produce household goods. Initially, this transaction was suspected to be nothing but money laundering, especially because at the end of 2004 the plant was scheduled for privatization, and its assets were estimated at only USD 900,000. Later, it was discovered that the plant had an order from the Russian Federation to produce certain sophisticated electronic devices. Things began to become clear when it was discovered that "Electroaparatnyi" participated in a weapons exhibition in the Russian Federation, where the plant had its own booth and it could either present a final product or certain components for weapons or military equipment, according to military experts. Thus, the order to the plant from the Russian Federation is in fact an order for the manufacture of electronic systems for the military. The missiles received from Russia have been re-equipped with devices produced at "Electroaparatnyi." This is how the line for the manufacture of weapons was established - weapons that might also have circulated as far as Iraq. ${ }^{20}$

The weapons trade has become an increasingly lucrative business for airway companies as well. On 10 May 2006, an Amnesty International report entitled "Dead on Time" which, in its analysis of the international arms trade, referenced a famous multimillion-dollar arms trading agency that dealt with companies from Israel, Switzerland, Bulgaria, and Great Britain. The agency launched its business with the help of the Moldovan airway company Aerocom. The paper outlined the ways in which the collapse of the Soviet Union had provided companies like Aerocom not only with huge amounts of cheap weapons to sell, but vast numbers of airplanes for transporting the weapons to conflict areas around the world. ${ }^{21}$ In March 2001, the Aerocom company was identified as having transported weapons to different regions in Africa and Middle East over the span of several years. The company used another African entity owned by Victor Bunt (without its knowledge) for the illegal transport of weapons by proxy. Another component of the case was the payment for the illicit transfers by a company registered in Ireland. Through these related connections and methods, the case illustrates the difficulties that Moldovan authorities are confronted with concerning the control of this illicit trade. Renan's Company was able to make three flights for weapon and force ammunition transportation from the Democratic Republic of Congo in June 2003. This correlates with the activities of the Moldovan company Aerocom, which was accused by international experts of being involved in the transport of approximately 200,000 AK-47 assault rifles from Bosnia to the coalition-backed Iraqi forces; the rifles never reached their intended destination in Iraq. The company's name has frequently appeared in UN and Amnesty International reports for its involvement in wars in Africa and Middle East. The 17 May 2006 edition of the magazine Counterterrorism wrote that there was no data that could tell us what has happened to the weapons bound for Iraq, but it is obvious that Aerocom took part in the venture. ${ }^{22}$ In

20 Ibid.

21 Amnesty International and TransArms, "Dead on Time: Arms Transportation, Brokering, and the Threat to Human Rights" (10 May 2006); available at http://web.amnesty.org/library/ index/engact300082006.

${ }^{22}$ See http://counterterrorismblog.org/2006/05/. 
the meantime, an African newspaper, Mail \& Guardian Online, wrote in its May 12 edition that Aerocom was criticized in a $2003 \mathrm{UN}$ report concerning the illicit diamond and arms trade in Liberia and Sierra Leone. Now the company has been shut down, but its assets and aircraft are registered under the name of another airway company from Moldova, known as Jet Line International. Four illegal flights were made from the "Eagle" air base in northeastern Bosnia without license. ${ }^{23}$

Analyzing these cases, it becomes evident that many small companies started their illegal activities by selling ammunition to governments, later expanding their activities as important distributors on the international market. Some commercial companies from Moldova, China, and Armenia have been sanctioned and accused of supporting Iran in its manufacture of weapons of mass destruction (WMD). Sanctions where imposed for a period of two years, by which time "not a single state or private company or natural person from the United States will have the right to contact commercially the representatives of the sanctioned companies." 24 The Reuters news agency has reported that the individuals working for the Moldovan companies could be a "screen" for Russian interests, because Moldova was a former Soviet republic. ${ }^{25}$ Moldova was listed as tenth in the world on a list of countries involved in the weapons trade. The Moldovan share of exported ammunition in the general exportation process is 2.1 percent, while Georgia and Belarus are responsible for 6.2 and 5.2 percent, respectively. Bulgaria took fifth place, with 5.1 percent; Ukraine and the United States shared sixth place; while Russia is in eighth place. But the study also found that none of the former Soviet countries was included in the top ten of the most militarized (paramilitary) countries and purchasers of ammunition. Russia is a leader only as an owner of a great atomic arsenal containing 24,000 warheads. Romania was the only country in the region that did not occupy any place in the top ten. Ukraine shared sixth place, with USD 550 million from export revenue with Australia and Canada, among the world leaders in the weapons trade. ${ }^{26}$

As hard as it is to link sex slavery with illegal arms purchases, it is arguable that the region's sex slave trade has enriched crime syndicates. Each year, approximately one million women are trafficked as sex slaves worldwide, with an estimated 200,000 passing through the Balkans. Human trafficking represents serious human rights violations on a massive scale. Already, Bosnia, Macedonia, Serbia, Montenegro, and Kosovo have become destination and transit countries, and Bulgaria, Albania, Macedonia, Romania, and Moldova have been identified as origin countries. While it is apparent that this business is flourishing, its actual scale is unknown. The absence of reliable regional data also makes it difficult to understand and track the problem.

Moldova and the self-proclaimed Republic of Transnistria, both wedged between Romania and the Ukraine, have been important factors in the geopolitical balance of

23 Ziarul de Garda (Moldova) 84:18 (18 May 2006); available at www.garda.com.md.

24 Announcement made by Richard Boucher, spokesman of the U.S. Department of State, at a press conference in Washington on 9 May 2002.

25 Ibid.

26 This conclusion was given by Russian experts in the journal Merchant-Money. 
South Eastern Europe for some time. Since 1991, the history of these two entities has not been a happy one: Moldova effectively lost part of its territory (and much of its industry) when the Transnistrian Republic declared its independence, which resulted in a brief but bloody war of secession in 1992.

Privatization, which ensued after the secession of Transnistria, impoverished the Moldovan population to such an extent that many Moldovans emigrated. Consequently, a flood of migrants has left Moldova in a desperate search for work. Thus, there are two main reasons for the preeminence of Moldova in this sad tale of trafficking. First, Moldova is nearer to the Balkan destination points for trafficked girls than Ukraine. Second, it has been reduced to grinding poverty, providing concrete incentives for young girls to wish to escape.

When tracing the common route through the Balkans to human trafficking and captivity, the pattern of events leading victims to this trap is fairly common. When they cross the border into Romania, they are usually taken by networks of Romanian pimps and "sold" at markets. One of these markets is said to be just outside Timisoara, near the border with Serbia. The price for a sex slave ranges from between USD 800 to as much as USD 5,000. Once they are bought, the girls are typically drugged and have their passports taken from them. In 82 percent of these trafficking cases, the purpose of the crime is sexual exploitation, which brings a high profit. As many as 83 percent of the victims are women from 14 to 26 years of age. Of this group, 15 percent are minors, 50 percent come from rural areas, and 80 percent come from vulnerable environments. Additionally, 85 percent of the trafficked women have not graduated from school, and in 90 percent of the cases they have no professional skills. ${ }^{27}$

Trafficked women are then smuggled across Serbia to Kosovo, Bosnia, Macedonia, or Albania, and in some cases also to Italy. Indeed, sex slavery is profitable not only for the pimps, whose earnings are immense, but also for "dealers," who can make USD 500-600 on each girl they sell for a price of USD 1,000-1,500. Statistical data and information about trafficking victims, including Moldovan citizens who have been exposed to sexual and labor exploitation and forced to commit criminal activities, is collected by the following organizations: Save the Children, La Strada Moldova (next to Gencliar Birlii), the International Organization for Migration's (IOM) Rehabilitation Centre, the Italian Solidarity Consortium, the Centre for Preventing Woman Trafficking, IOM Mission in Chisinau, the Young Generation (Romania), Koofra (Germany), and the Poppy Project (Great Britain). ${ }^{28}$

The final destination of many trafficked women is the Balkans, especially Kosovo and Macedonia. But a large number of victims are also taken to Italy. In the recent past there has been an exponential increase in the power of the Albanian mafia in Italy, which was documented in a 1998 report submitted to the United Nations (UN) by the

27 Rebecca Surtees, Second Annual Report on Victims of Trafficking in Human Beings in South Eastern Europe (Geneva: International Organization for Migration, 2005); available at www.iom.int/jahia/webdav/site/myjahiasite/shared/shared/mainsite/published_docs/studies_ and_reports/second_annual05.pdf.

Ibid. 
former head of the Italian anti-narcotics unit, Prefect Pietro Soggiu. He worked together with the UN anti-drug chief, Pino Arlacchi, who declared in 1999, "The Albanian Mafia has reached a remarkable level of organization, with branches in Italy and Germany, and it has succeeded in obtaining control of the Balkan route for drug trafficking, to which it has added the trade in illegal immigrants, arms and munitions." 29 At present, the Moldovan state does not have the means to register the movement of its citizens abroad, although evident transit routes and modes of transport can be identified with the help of information provided by the victims who were aided in 2003 and 2004. Findings from interviews with victims include the following insights:

- To reach the Balkans, victims pass through the southern part of Moldova (Cahul and Vulcanesti), then to the Virzac district in Romania, and on to Serbia.

- To reach Western Europe, victims pass through Romania, Serbia, and Montenegro or Albania to Italy (by sea), Slovenia, and Hungary.

- To reach Russia and Ukraine, victims pass through Moldova by automobile or train.

- To reach Turkey, victims passed through Ukraine; coming from Moldova, they pass through the seaport of Odessa and are consequently "delivered" by ship.

An especially appalling aspect of the trade in human beings is the sexual exploitation of children. Mariana Petersel, director of Save the Children in Moldova, attributed some of the problems to the families themselves. Family structures have been broken down by seventy years of communism, she said, and this meant that parents were sometimes prepared to sell their own children into slavery. It is assumed that the prices she mentioned-USD 7,000 to 8,000 - are for underage slaves, since, as has been shown above, the price for adult girls is much lower, at USD 1,000 to $1,500 .^{30}$

There was a case in which a mother sold her newborn child to traffickers, who took the child abroad for foreign adoption. Beginning in 1998, almost 300 Moldovans sold their kidneys, the majority of them having been forced to do so. In addition to this, several people were arrested for selling human organs in 2002. The arrests were made after the victims gave statements to the police, although none of the cases were pursued, and victims were not given medical aid. ${ }^{31}$

The following case can serve as an example of transborder criminal structures. In October 2001, Romanian police disrupted a human trafficking ring that was being guided by Gorceac Svetlana, a Moldovan citizen. From 2000 to 2001, with the help of other Moldovan, Romanian, and Serbian individuals, Svetlana recruited and trafficked a great number of young girls from Romania and Moldova to the former Yugoslavia,

29 British Helsinki Human Rights Group, Country Report, "Sex Slaves: Trafficking in Human Beings from Moldova to Italy" (n.d.); available at www.bhhrg.org/CountryReport.asp? ReportID=160\&CountryID=16.

30 Ibid.

31 Rebecca Surtees, Regional Clearing Point's Second Annual Report on Victims of Trafficking in South Eastern Europe (Geneva: IOM, July 2005); available at www.iom.int. 
promising well-paid jobs abroad, mainly in Western Europe. The Moldovan girls were attracted by these false job announcements. Authorities identified and interviewed thirty-three trafficked victims through the networks directed by Gorceac Svetlana in order to prosecute her. Starting on 6 August 2001, using information obtained with the help of the Regional Centre for Southeast European Cooperative Initiative, police officers and Federal Bureau of Investigation (FBI) agents established a task force at the Ministry of Internal Affairs. The team launched a special operation targeting Gorceac Svetlana and her criminal networks within Romania and the former Yugoslavia. They discovered that she was renting apartments in Timisoara to house victims before trafficking them to Yugoslavia. On 22 October 2001, officers within the Romanian Ministry of Internal Affairs identified an apartment owned by Gorceac Svetlana in Timisoara, where she and three other persons were detained as being her accomplices. ${ }^{32}$

Recent findings indicate that there are increasing numbers of cases in which perpetrators of human trafficking crimes describe themselves as former trafficking victims. These people were released from harsh slavery only to return back to their native country with the mission to recruit new victims. They were threatened-told that their names would be made known, and that public opinion would ostracize them-in order to force them to commit these crimes. There are only rare situations in which some voluntarily attempt to transform this occupation into their own businesses. Transborder networks are the essential elements in managing these trafficking operations. These networks subordinate small trafficking groups and individuals engaged in this process.

In specialized literature, ${ }^{33}$ pimps are classified in three categories, the classification being characteristic for the Republic of Moldova:

- Occasional traffickers (on the frontier territory). These traffickers transport victims internally and internationally. They are often taxi, boat, or pickup truck owners who can pass individuals or small groups of people across borders using familiar places. In sections of the Danube River, for example, boatmen are well paid for the transportation of victims to the Serbian side. The transit routes across the Danube are used with great discretion, and departure points always differ. Once the traffickers reach Serbia, the victims are transferred to other individuals, this time Serbians, and are later distributed to regional restaurant owners. In this way, the majority of trafficked victims never reach Western Europe, but remain somewhere near Romania. ${ }^{34}$

32 Trafficking in Children for Sexual Exploitation in the Republic of Moldova (Chisinau: Centre for the Prevention of Trafficking in Women, 2003); available at www.ecpat.net/eng/ Ecpat inter/projects/promoting law/East-West_Research-2004/Moldova_ENG.pdf.

33 The international legislation on Trafficking in Human Beings, Ural Centre for NGO Assistance, Permian Center against Violence and Human Trafficking, Russian Federation (2000), 23.

34 "The Danube Smugglers Change their Direction: Women Instead of Petrol," Evenimentul Zilei (Romania) (28 March 2002). 
- Gangs or small trafficking groups. These are well-organized groups that usually specialize in trafficking citizens outside the origin country and consistently use the same routes. These groups can be permanent or temporary in nature, and are based on personal relations among group members.

- International trafficking networks. These networks are the most sophisticated, dangerous, and difficult to combat of all trafficking groups. The network members who are present in origin, transit, and destination countries either have access to false and certified documents or steal or falsify them by themselves. They are able to modify routes or transport methods when the usual passageways are blocked. Natives of countries where trafficking is taking place have assumed special roles in these structures; their presence has become increasingly prominent. ${ }^{35}$

The members of the Combating Trafficking in Human Beings Directorate maintain that trafficking is a separate business, but one that has strong connections with other types of criminal structures and activities. Crimes associated with trafficking in human beings imply the following necessary elements:

- The identification and recruitment of persons who, despite ranging in age from 18 to 30 years old, may be sold for sexual exploitation purposes

- The search for external "markets" abroad for the sale of trafficked victims (including the participation of foreign proxies)

- The transportation of victims across borders (using foreign passports and other certified documents, or using false documents)

- The establishment of contacts with corrupt officials, who are implicated in securing necessary documents for the movement of victims across the Moldovan border

- The securing of payments due for the "delivery" of victims abroad. ${ }^{36}$

\section{Conclusion}

Recently, Bulgaria and Romania joined the North Atlantic Treaty Organization (NATO) and the European Union (EU). Regardless of these accomplishments, these countries are still confronted with a security threat posed by a high level of all forms of organized crime. The countries of the western Balkans are in an even worse situation, due to their history over the past decade and their lack of experience in dealing with these problems. In the present context, "nobody can afford the luxury of a fractious Balkans," and this must be made clear to the United States and the EU, as they "feel compelled to divert political, military, and financial resources away from the region and

35 "Trafficking in Women in European Union: Characteristics, Trends and Politics," European Conference on Trafficking in Women (June 1996).

36 Interview given by Mr. Ion Turcan, Head of Department, the Ministry of Internal Affairs of the Republic of Moldova, 29 August 2002. 
into their struggle against terrorism." ${ }^{37}$ Analyzing the dramatic political and societal aspects of criminal activities, it is apparent that organized crime in Ukraine has become a significant political and economic force; collusive and corrupting relationships with the political elite have developed and exert influence over many sectors of the economy. Politics, crime, and corruption have merged to form both a deeply criminalized political system and highly politicized criminal organizations. Organized crime groups are well established in Dnipropetrovsk, Zaparozhe, Lugansk, Kharkiv, Odessa, Crimea, and Kiev.

Transnational organized crime is a considerable dilemma, and represents a complex phenomenon in South Eastern Europe, one "linked with warlordism and terrorism," meaning that any attempt to deal effectively with any one of these problems requires "dealing with the others as well — either at the same time or sequentially — because each one feeds off the other." ${ }^{38}$ Criminal organizations have therefore become a global concern. Trafficking networks are expanding into legitimate economies, making their activities and philosophy more pervasive. One important factor that must be reconsidered is education, which is the essential instrument in counteracting the negative impacts of the trafficking process.

37 Misha Glenny, "Heading off Terrorism in the Balkans," New York Times (16 October 2001). nated, Multi-level Approach," paper presented at the 4th Reichenau Workshop of the PfP Consortium Working Group on Regional Stability in South East Europe, "Crushing Crime in South East Europe: A Struggle of Domestic, Regional and European Dimensions," Reichenau, Austria, 16-19 May 2003. 


\section{Bibliography}

Ambroci, Mr. Ion. Extracted from the report presented at the PfP Counter-Terrorism Working Group (CTWG) meeting in Moldova., 2006.

Analysis on Narcotics Situation in the Republic of Moldova., 2005.

Balkan-Albania-Kosovo-Heroin-Jihad, Research Analysis. Toronto: The Center for Peace in the Balkans, 2000.

Borov, Zaur, and Stephen Bowers. Illegal Weapons Traffic in Eastern Europe. Harrisonburg, VA: Nelson Institute for International and Public Affairs, James Madison University, 2002.

Busuncian, Tatiana. Terrorism and Organized Crime" report presented within the "NATO Defense against Terrorism Course. Oberammergau, Germany: the NATO School, 2004.

Country Factsheets Eurasian Narcotics: Ukraine 2004., 2004.

Dead on Time: Arms Transportation, Brokering, and the Threat to Human Rights. Amnesty International and TransArms, 2006.

Ghencea, B., and I. Gudumac. Labour Migration and Remittances in the Republic of Moldova. Kishinev, Moldova: Microfinance Alliancea, and Chisinau: Soros in the Republic of Moldova, 2004.

Glenny, Misha. "Heading off Terrorism in the Balkans." New York Times (2001).

Guarding the Rusty Cartridges as Shield for Modern Military Technology. Journalistic Investigations Center, 2004.

Hutchinson, Asa. Congressional Testimony before the Senate Judiciary Committee's Subcom-mittee on Technology, Terrorism and Government Information about NarcoTerror: The World Connection Between Drugs and Terror., 2002.

Informative note for the National Migration Department of the Republic of Moldova on "Trafficking in Human Beings. National Migration Department of the Republic of Moldova , 2003.

Migration, Employment and Poverty Reduction. Moldovan Ministry of Health and Social Protection, 2005.

Mission Reports - Visit to Moldova by the Subcommittee on Democratic Governance [Civil Dimension of Security]. In NATO Parliamentary Assembly., 2004.

Moldova - A Bridge for Trafficking In Geopolitical Drug Newsletter. 7th ed. Vol. 2002. Centre for Geopolitical Drug Studies, 2002. 


\section{THE QUARTERLY JOURNAL}

Sandole, Dennis J. D.. "Combating Crime in Southeastern Europe: An Integrated, Coordinated, Multi-level Approach." In 4th Reichenau Workshop of the PfP Consortium Working Group on Regional Stability in South East Europe, on Crushing Crime in South East Europe: A Struggle of Domestic, Regional and European Dimensions. Reichenau, Austria, 2003.

Sex Slaves: Trafficking in Human Beings from Moldova to Italy. British Helsinki Human Rights Group, Country Report, 2001.

Surtees, Rebecca. Regional Clearing Point's Second Annual Report on Victims of Trafficking in South Eastern Europe. Geneva: IOM, 2005.

Surtees, Rebecca. Second Annual Report on Victims of Trafficking in Human Beings in South Eastern Europe. Geneva: International Organization for Migration, 2005.

The Danube Smugglers Change their Direction: Women Instead of Petrol. Evenimentul Zilei (Romania) (2002).

Thomas, Brian Johnson, and Mark Franchetti. "Radioactive Rockets 'For Sale' in Breakaway Soviet Republic." Times (2005).

Trafficking in Children for Sexual Exploitation in the Republic of Moldova. Chisinau: Centre for the Prevention of Trafficking in Women, 2003.

Trafficking in Women in European Union: Characteristics, Trends and Politics. InEuropean Conference on Trafficking in Women., 1996.

UN Warns about Nexus Between Drugs, Crime and Terrorism. United Nations, 2004. Ziarul de Garda (Moldova). Ziarul de Garda (Moldova) 84, no. 18 (2006). 